\title{
The Effect of Using Clustering Technique On Students' Achievement in Writing Descriptive Text
}

\author{
Ratna Sari Dewi ${ }^{1}$, Vira Ayunisa ${ }^{2}$ \\ ${ }^{1,2}$ English Education Study Program, University of Muhammadiyah Sumatera Utara \\ ratnasari@umsu.ac.id
}

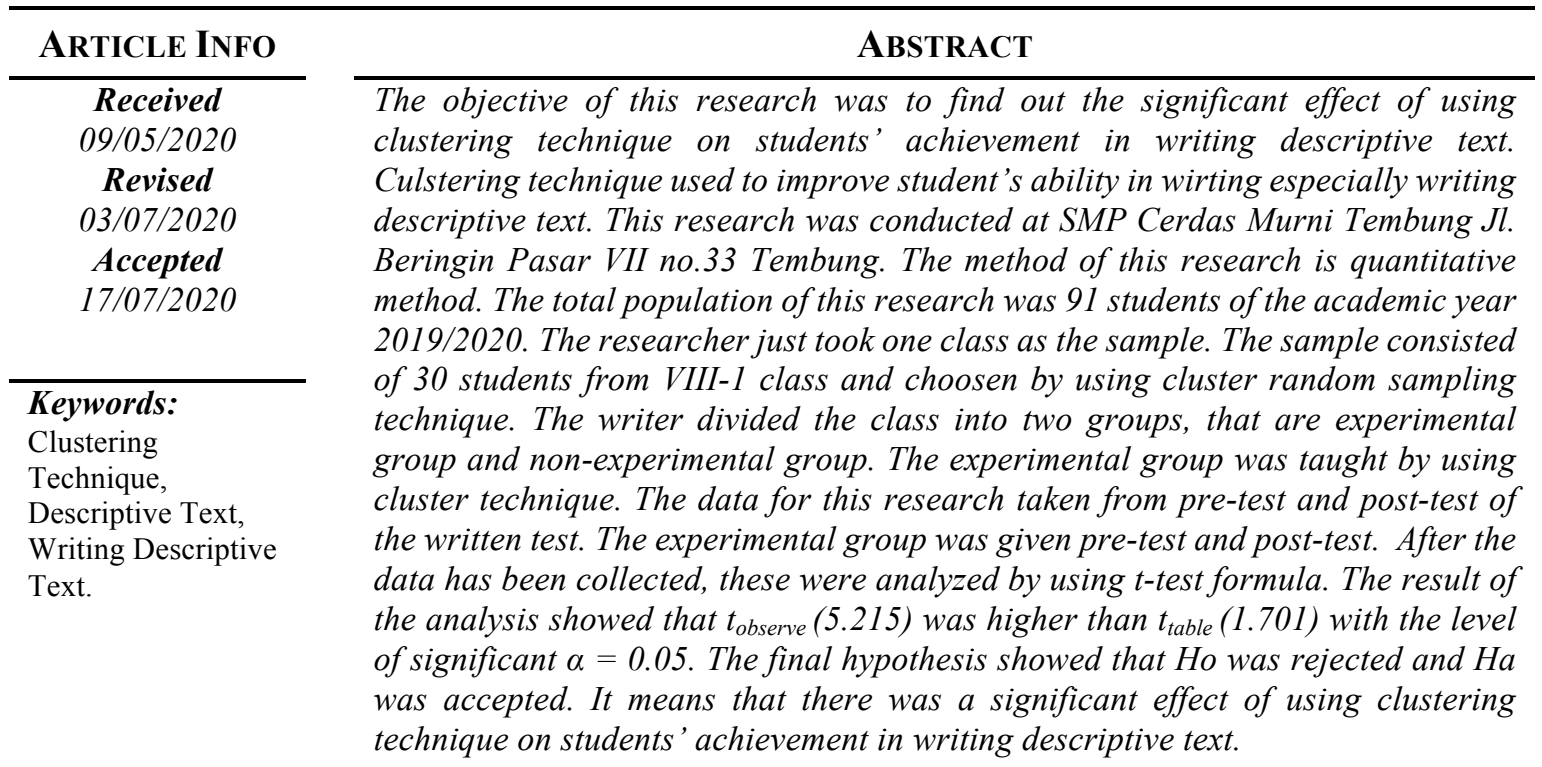

How to cite: Dewi, R. D, Ayunisa, V. (2020). The Effect of Clustering Technique On Students'

Achievement in Writing Descriptive Text. English Teaching and Linguistics Journal, 1(2), 41-43.

\section{INTRODUCTION}

In learning English, there are four basic language skills that should be mastered by students. They are speaking, listening, reading and writing. In reading and listening, students did not have to produce language, they receive and understand it. On the other hand, in speaking and writing which also known as active skills. In this skill, learners should produce the language. According to Harmer (2004:31) writing as one of the four basic language skills has always formed part of the syllabus in the teaching of English. Moreover, Ghufron (2014) states that writing as a skill involves a number of complex rhetorical and linguistic operations which must be taught.

It's a good way to help the students for develop their English ability. According to Raimes (1983), writing becomes important because of some reasons. First, it can help the students to reinforce the grammatical structures, idioms and vocabularies that already taught by the teacher. Second, when the students do write, they also have a chance to be daring with the language. Third, when they write, they need to be involved with the new language; the effort to express ideas and the constant use of eye, hand and brain is a unique way to reinforce learning. Besides, a good writing must comprise with some aspects. Refers to Andriyani (2017:2), writing needs the mastery of several skills. It includes: language use or grammar, punctuation, capitalization, spelling and correct vocabulary in composing ideas. Students have a good ability if they can arrange their ideas into written form in correct vocabulary with full attention in language use grammar, punctuation, spelling, capitalization in their sentence.

In spite of writing is a good way to help the students for developing their English ability. Most of students find that writing is difficult skill to be learned moreover writing in second 
language. It called difficult because first, the students should be able to master vocabulary, grammar, organization and mechanics. Second, they need hard thinking to arrange the words into sentences and arrange the sentences into paragraph until they can create a piece of written text. And the last, they need to translate their ideas into a readable text.

Meanwhile, based on the curriculum there are some types of the text that have to be mastered by students, they are recount, narrative, procedure, and descriptive text. The problems can be divided into two factors, first is the internal and the last is the external factors. The internal factors of the student problems are from themselves, that are: the student doesn't know how to start during writing especially in writing descriptive text. Second, the students are not interested in studying writing in the class. The external factor of the student problem is the teacher. The teacher usually asked students to write without using the appropriate technique to develop their writing.

One of the techniques that can be used in teaching writing is clustering technique. A clustering technique is also known as diagramming or mapping. This technique is developed by Gabrielle Luser Rico, a professor of English and Creativity at San Jose University, California 1980's. Caswell and Mahler (2004:55) say that clustering technique is appealing for two reasons. First, it is a way to organize the ideas from a brainstorm list into categories, which each branch representing a different paragraph. Second, it is visual, so it appeals to specific learning styles. According to Gufron (2014:9) "Clustering technique is a technique to divide some related ideas and write down in a blank paper without evaluating the truth or value of the ideas themselves".

Clustering technique can be possible to do with pen and paper or with a marker and whiteboard. The procedures to do clustering technique are: first student place the main topic in the center of paper and drawing a circle around it. Then, continue with related words, ideas which come to mind, circle it again, and make the line to connect it to the main topic. Finally, teacher may stop the students after times up, and then they can check the cluster and pick the subtopics that interest them.

Based on the explanation above, the researcher chooses clustering technique to help the students to face the problem when writing a descriptive text. Thus, the writer decides to choose this study entitled "The Effect of Using Clustering Technique on Students Achievement in Writing Descriptive Text."

\section{METHODS}

The method that used in this study is quantitative method (Sugiyono, 2013). It is used to see the effect of clustering technique on students' achievement in writing descriptive text. The location in this research conducted at SMP Cerdas Murni in Tembung. The population of this research are the eight grade students of SMP Cerdas Murni which consist of three classes that are class 8-1 consists of 30 students, class 8-2 consists of 30 students and class 8-3 consists of . So, the total population of this research is 91 students. Class viii- 1 was chosen as experimental group and taught by using clustering technique. In doing this research, there are three steps namely pre-test, treatment and post-test. The data are taken from the students' writing skill in descriptive text. In order to get the data, a written text used as the instrument of the study which used to cumulative the five aspects such as content, organization, grammar, vocabulary and mechanism (Brown, 2004).

Techniques of collecting the data are: giving pre-test, treatment, post-test and listing the scores of pre-test and post-test into table for the experimental group. After collecting the data from the test, then the data will be analyzed by finding the correlation, t-test, testing linear regression and finding the significant effect of clustering technique (Sugiyono, 2015).

\section{RESULT AND DISCUSSION}

The data of this study obtained from the test scores. There are two tests for the experimental group that are pre-test and post-test. To calculate the score of experimental group, this study used five aspects from Brown (2004:246) that are: content, organization, grammar, 
vocabulary and mechanism. The highest score of pre-test is 9.5 , the lowest score is 2.5 and mean score is 5.58. The next test is post-test which has the result is the highest score is 10 while the lowest score is 7.5 and mean score is 8.80 . the result shown that there is an increase after using clustering technique on students' writing achievement in descriptive text.

After taking the two test, then making the correlation between these two tests using the following formula:

$$
\begin{aligned}
\mathrm{rXY}= & \frac{\mathrm{N} € \mathrm{XY}-(€ \mathrm{X})(€ \mathrm{Y})}{\sqrt{\left(\mathrm{N} € \mathrm{X}^{2}-(€ N)^{2}-\right.}\left(\mathrm{N} € \mathrm{Y}^{2}-(\mathrm{Y})^{2}\right)} \\
& =0.7
\end{aligned}
$$

From the formula above, we can see that the result of the correlation is 0.7 .

After finding the correlation of the test, next is determining the data by using t-test (Sugiono, 2015) and determination using this formula below:

T-Test formula: $\mathrm{t}=\mathrm{r} \frac{\sqrt{\mathrm{n}-2}}{\sqrt{1-\mathrm{r}^{2}}}$

$$
=5.125
$$

Determination formula:

$$
\begin{aligned}
\mathrm{D} & =(\mathrm{rXY})^{2} \times 100 \% \\
& =(0,7)^{2} \times 100=49 \%
\end{aligned}
$$

By using the formula above, we can see the result of the determining of t-test is 5.215. Based on the testing of hypothesis, the value of $t_{\text {observe }}>t_{\text {table, }}, 5.215>1.701$. it means that there is a significant effect of using clustering technique on students' achievement in writing descriptive text. The value of the effect is about $49 \%$.

\section{CONCLUSION AND SUGGESTION}

Based on the data analysis, the conclusion is that there was a significant effect of using clustering technique on students' achievement in writing descriptive text which proved by the result of the score of pre-test before giving treatment was 167.4, and the post-test after treatment was 264.2 and it was found that the $t_{\text {observe }}>t_{\text {table }}$ or $5.215>1.701$. so, the null hypothesis $\left(\mathrm{H}_{\mathrm{o}}\right)$ was rejected and the alternative hypothesis $\left(\mathrm{H}_{\mathrm{a}}\right)$ was accepted.

Some suggestions are put forward as the following:

1. The English teachers are expected to use clustering technique in teaching writing, especially descriptive text.

2. The students are expected to use clustering technique before writing descriptive text because it can help to gather their idea so they can easier to write descriptive text.

\section{REFERENCES}

Harmer, J. (2004). How to Teach Writing. England: Longman.

Ghufron, A. M. (2014). The Implementation of Clustering Technique to Improve Students'

Writing Skill in Descriptive Text of the Eight Grade of MTs Darul Ulum Purwosari

Sukosewu Bojonegoro in The Academis Year 2012/2013. Jawa Timur: IKIP PGRII Bojonegoro.

Raimes, A. (1983). Techniques in Teaching Writing. Oxford American English.

Andriyani, T. (2017). Teaching Writing on "Descriptive Text" for The First Grade of SMP N 03 Mojogedang Karanganyar in the Academic Year of 2014/2015. Thesis. Surakarta: IAIN Surakarta.

Caswell, R \& Mahler, B. (2004). Strategies for Teaching Writing. England: Longman.

Sugiyono. (2013). Metode Penelitian Pendidikan Pendekatan Kuantitatif Kualitatif. Bandung: Alfabeta.

Brown, H. D. (2004). Language Assessment Principles and Classroom Practice. California: Pearson ESL.

Sugiyono. (2015). Metode Penelitian Kombinasi. Bandung: Alfabeta. 